\author{
Magdalena Charzyńska-Wójcik \\ The John Paul II Catholic University of Lublin
}

\title{
Between the text and the page: Żołtarz Dawidów in manuscript and print ${ }^{*}$
}

\begin{abstract}
The objective of the paper is to argue against a common denotation for Walenty Wróbel's $16^{\text {th }}$-century translation of the Psalter into Polish and its printed version prepared by Andrzej Glaber. It is customary to treat Glaber's interventions into Wróbel's rendition as purely editorial and, in effect, consider the printed version of the Żottarz to be the work of Wróbel. On the basis of Glaber's treatment of one syntactic phenomenon (the placement of the possessive pronoun in an NP), the paper shows that Glaber's involvement into Wróbel's text far exceeds what Glaber is usually credited with. Therefore, the paper claims that the two works - the manuscript and its printed edition - should be classified and discussed as distinct productions.
\end{abstract}

\section{Keywords}

Psalter, Walenty Wróbel, Andrzej Glaber, manuscript, print, syntax of NP, Biblical translation

\section{Streszczenie}

Celem artykułu jest ukazanie rozbieżności pomiędzy polskim Psałterzem w XVI-wiecznym przekładzie Walentego Wróbla a jego drukowanym wydaniem przygotowanym przez Andrzeja Glabera. Przyjęło się sądzić, że interwencje Glabera w tekst Wróbla miały charakter wyłącznie redakcyjny i w związku z tym drukowaną wersję Żołtarza uważa się za dzieło Wróbla. Analiza sposobu, w jaki Glaber potraktował jedno wybrane tu dla przykładu zjawisko składniowe (pozycja zaimka dzierżawczego w stosunku do członu głównego we frazie nominalnej), ukazuje, że stopień interwencji Glabera w tekst Wróbla znacznie przekracza zakres interwencji redakcyjnych, o jakich czytamy w literaturze przedmiotu.

* I would like to thank Professor Tomasz Jasiński, Director of the Kórnik Library, for allowing me to work with the manuscript of the Żoltarz and for his generous support. I also owe a debt of gratitude to the library staff for their kind help during my stay there. Also I would like to thank two anonymous SPL reviewers of this paper for their insightful comments. It is following their suggestion that I present Wróbel's dotted $\langle\ddot{y}\rangle$ as $\langle y\rangle$, i.e. without retaining the distinction between the two types of $<y>$ which obtains in the manuscript. Apart from that, the text is always represented exactly as in the original sources, i.e. the Kórnik manuscript and the printed version of the Żottarz, even when it seems to contain errors. 
Dlatego też artykuł stawia tezę, że obie wersje tekstu - rękopiśmienną i drukowaną - winno się traktować jako odrębne dzieła.

\section{Słowa kluczowe}

Psałterz, Walenty Wróbel, Andrzej Glaber, rękopis, druk, składnia frazy nominalnej, tłumaczenie biblijne

\section{Introduction}

The incentive behind writing this paper was a desire to bring to light some unknown aspects of a relatively well-known $16^{\text {th }}$-century Polish translation of the Psalter executed by Walenty Wróbel soon before 1528 and entitled Żołtarz Dawidów. This is not to say that Wróbel's Żołtarz is a very well-known production but that researchers who specialise in Biblical translations into Polish or more generally in the Polish literature of the period are familiar with this work, cf. Brückner, Łoś, Rospond, Kossowska, Kwilecka, Migdał, Michałowska, Cybulski, Koziara, Wodecki, Pietkiewicz, Kamieniecki, Badowska, to mention but a few. So was I. I worked on several aspects of this Psalter: on the sociolinguistic context in which it emerged and the readership of the Żottarz (Charzyńska-Wójcik in press a). I offered a preliminary analysis of the syntax of this rendition and its convergence with the Latin source (Charzyńska-Wójcik in press b). I examined Wróbel's translation technique against the prospective addressee of the Żoltarz (Charzyńska-Wójcik 2016a). Being aware of the fact that the printed text available for study was edited by Andrzej Glaber from Kobylin without Wróbel's supervision or participation, I compared the mise-en-page of the manuscript of the Żottarz (to which there is no internet access) with a printed copy of that page and pointed out how profoundly Glaber intervened into Wróbel's original idea of the work (Charzyńska-Wójcik 2015, 2016a, 2016c). But it was not until I got to work with Wróbel's manuscript myself that I realised the full extent of Glaber's interventions into Wróbel's Żottarz. They affect several aspects of the work and are tackled by different researchers from varying perspectives, depending on the focus, but whatever conclusions they reach, they underestimate Glaber's contribution to the final shape of the printed work.

Contrary to the general view (cf. Section 2), Glaber's interventions into Wróbel's Żołtarz not only affect the form and textual ingredients but also significantly alter the text of the rendition. That is why in this paper I am going to argue in favour of introducing a distinction between Wróbel's original work, which is now available in a single manuscript copy in Kórnik ( $\mathrm{ms} 7$ ), and Glaber's edition of that work, i.e. the production which is generally accessible and is referred to in the literature as Wróbel's Żoltarz Dawidów. I will support this claim by the data concerning Glaber's interventions into the syntax of the 
Noun Phrase, in particular the placement of the possessive pronoun with respect to the head noun (Section 3). Moreover, I will discuss my data against the backdrop of the information circulating in the literature concerning the same phenomenon. This will be done in order to show that the two productions differ significantly to the effect that they should be viewed as different texts but the genuine extent of these differences is not properly appreciated in the literature. Section 4 will show that the conclusions following from the analysed data offer support to the above view, while a post scriptum given in Section 5 will offer justification for such a profound modification of Wróbel's work on the part of Glaber, underscoring the differences between the modern idea of authorship and its 16th-century understanding and implementation.

\section{The general view}

Although the literature on Wróbel's Żołtarz and its edition prepared by Glaber is not impressively large, it is impossible to discuss it in detail within the confines of this paper, but a comprehensive review of the relevant information is offered in Charzyńska-Wójcik (in prep.). However, let me present the necessary preliminaries before moving on to the discussion of the data to place it in its proper context.

Walenty Wróbel, a professor of the Cracow Academia and Catholic priest, ${ }^{1}$ was commissioned by Katarzyna Górka from Szamotuły, the wife of the Governor of Poznań, to prepare an accessible translation of the Psalter accompanied by approachable commentary explaining its deep sense. ${ }^{2}$ The intended addressees of this production, as we learn from the Prologue to the printed edition, were nuns who sang the Psalter daily, according to the requirements of the horarium, without necessarily understanding its words. Wróbel undertook the job and prepared a translation of the book of Psalms which met all demands of the commissioner: it contained the Polish text of the Psalms accompanied by ample commentary. Moreover, above each Polish verse, he placed an incipit of the corresponding Latin verse, which made it possible for a reader to relate the text to the liturgical Latin Psalter of the Vulgate, i.e. the Gallicanum. It is important to emphasise at this point that Wróbel's Żołtarz Dawidów is the first fresh translation of the Psalter into Polish, i.e. it does not rely on the existing texts: the Floriański, Puławski and Krakowski Psalters. ${ }^{3}$

${ }^{1}$ A biography of Wróbel is offered in Kossowska (1968).

${ }^{2}$ For the sociolinguistic context in which this translation emerged, see Charzyńska-Wójcik (2016a); for its place in a yet broader context of vernacular translations of the Bible and strategies of appropriating it to the estimated intellectual capacity of the addressees see Kwilecka (1978).

3 The Krakowski Psalter claims to be a new translation from Latin ("nowo pilnie przelożony z łácińskiego ięzyka w polski”), but it represents, like the Floriański and Puławski Psalters, the same textual family, i.e. based on or derived from the Kinga's Psalter (cf. Brückner 1902: 18). 
Wróbel's work was extremely popular and circulated in manuscript for several years. One of the copies was thoroughly examined by a committee of theologians of the Cracow Academia (Brückner 1902: 68), who proclaimed its orthodox character (Kossowska 1968: 107) and recommended the Żołtarz for print. The job of editing this rather complicated text was entrusted after Wróbel's death in 1537 to Andrzej Glaber from Kobylin ${ }^{4}$ (Brückner 1902: 68; Kossowska 1968: 98; Michałowska 1995/2002: 580; Migdał 1999: 23; Cybulski 1996: 70, 2008: 35; and Badowska 2011: 102). In effect, Glaber prepared Wróbel's Żołtarz without consulting Wróbel at any stage. So, whether Wróbel would agree with Glaber's interventions or not - we do not know.

From the opinions circulating in the literature, starting with Brückner (1902), through Łoś (1915), Kossowska (1968), Michałowska (1995/2002), Migdał (1991, 1999), Cybulski (1996, 2008), Pietkiewicz (2002, 2010, 2013), etc., we find out that the most important of Glaber's interventions was adding the Latin text in full, while, as noted above, Wróbel's manuscript had only the incipits. Wróbel's comments, which were mostly placed on the margins, were relocated to the main column of the text. Moreover, Glaber modernised Wróbel's orthography and morphological forms, replaced (most of) the dialectal forms and some obsolete lexical items with what he considered their more suitable equivalents. Occasionally, we learn, Glaber adjusted the syntax, especially within the NP, where he relocated Wróbel's preposed possessive pronouns to the postnominal position in accordance with the requirements of Polish Biblical style. ${ }^{6}$ This observation is due to Migdał (1991: 90), who on the basis of the text of Wróbel's translation (in contrast to the text of the commentary) reports the existence of eleven relocations of this type. The same amount of relocations of this type is given by Cybulski (1996: 76). ${ }^{7}$ And it is precisely these relocations that I will focus on in the next section.

\section{The NP: a comparison between Wróbel's and Glaber's syntax}

In view of Migdał's (1991, 1999) impressively scrupulous classification of Glaber's corrections of Wróbel's text with special focus on spelling, phonology and morphology, I was struck by a lack of consistency as far as Glaber's

${ }^{4}$ Glaber's biography is presented in Migdał (1999).

${ }^{5}$ Migdał (1999: 23) emphasises Glaber's appointment for the editing of Wróbel's work by the members of the Cracow Academia (Łoś 1915: 175; Michałowska 1995/2002: 580) as a sign of Glaber's respected position in contemporary academic circles.

${ }^{6}$ Cf. Kossowska (1962), Rospond (1962), and Koziara (1998).

${ }^{7}$ Detailed comments on Migdał's and Cybulski's data are presented in Charzyńska-Wójcik (in prep.). 
word order rearrangements are concerned. This was my initial impression, with plenty of syntactic rearrangements working in either direction, so the statement concerning Glaber's consistent postposing of possessive pronouns from a prenominal position aroused my curiosity. I decided to examine the manuscript and the printed text from the perspective of the placement of possessive pronouns in Noun Phrases to see if these data confirm my impression of inconsistency. Even a preliminary analysis revealed that the data show more variability than Migdał's observation seemed to announce, in effect supporting the hypothesis that Wróbel's text is not sufficiently researched, all too often being identified with Glaber's production. Let me present the results of my research.

I examined each of the three texts: the source text, i.e. Gallicanum and the two versions of the translation, i.e. Wróbel's and Glaber's, to extract the NPs consisting of the head noun and a possessive pronoun. I worked with the Latin text of Glaber's 1539 edition on the assumption that Wróbel's and Glaber's copies of the Gallicanum represented the same text. ${ }^{8}$ As for the Polish texts, I worked with Wróbel's rendition as presented in the Kórnik manuscript and Glaber's text from Ungler's 1539 printing. I decided to examine the first 100 NPs and see what conclusions can be drawn from these data.

Interestingly, the first 100 NPs from the Latin source did not coincide with the first 100 Polish NPs with the same constituents in either version of the Żoltarz. This is predominantly because the Polish text(s) often add(s) elements that are not attested in the source ${ }^{9}$ but also due to the linguistic differences between Latin and Polish. ${ }^{10}$ So, in order to pair up the three texts it was necessary to exclude the NPs that either do not represent translations or do not correspond to NPs in the Latin source. I did not discard these data, however, since quite a lot of interesting observations follow from an analysis of these cases as well. Below I will first present the results of my analysis of Glaber's interventions into Wróbel's translation ${ }^{11}$ of the first 100 Latin NPs, and then I will discuss Glaber's corrections of Wróbel's NPs which do not have equivalents in the

8 This is claimed on the authority of Kossowska (1968: 107), who observes that Wróbel and Glaber probably used the best copy of the Vulgate available in their time. It follows, then, that the text they worked on was common for the translator and the editor, as the author puts it. Moreover, Kossowska (1968: 107) remarks that Glaber certainly knew very well what text to use.

${ }^{9}$ It needs to be emphasised that these added elements are presented as translation, i.e. seamlessly interwoven into the text in sections devoted to translation.

${ }^{10}$ What I mean by that are instances where for example a monotransitive verb like confidere 'to trust,' which normally appears in Latin with a prepositional object, is translated by a ditransitive verb of the type 'to place trust in somebody', as in the following example from 2.13: confidunt in eo 'trust in Him' > wnym duffanye swe pokladayą 'in-Him trust their place.' In effect, the Polish texts show NPs where the Latin source does not have them.

${ }^{11}$ For obvious reasons I focused on the translation to the exclusion of the commentary. 
Latin source. ${ }^{12}$ The data of the second type are hoped to shed some light onto the realisation of Polish Biblical style independently of the fidelity of the translation proper.

\subsection{Translation proper}

Starting with the translation proper, the 100 Latin NPs, which are contained within Ps. 1.1-8.4, all exhibit the postposition of the possessive pronoun, i.e. the order typical of Latin. However, not all of their Polish equivalents qualify for the comparative analysis described above on account of the differences in the target structure. In particular, I excluded from comparison all instances in which the Polish text(s) do(es) not show a head noun and a possessive pronoun structure (in either order). ${ }^{13}$ This necessitated eliminating 14 contexts of the type: 1.2: lege eius 'his law' > (w)timze zakonye 'this law' (Wróbel) > (w)timże zakonie 'this law' (Glaber). The remaining 86 contexts, however, can be compared and the results of my analysis are presented in Tables 1 and 2 below.

\begin{tabular}{|c|c|c|}
\hline & Wróbel & number of cases \\
\hline 1. & $\mathrm{~N}+\mathrm{pp}^{14}$ & 83 \\
\hline 2. & $\mathrm{pp}+\mathrm{N}$ & 3 \\
\hline & TOTAL & 86 \\
\hline
\end{tabular}

Table 1. Ordering in NPs of Wróbel's translation of the Gallicanum

\begin{tabular}{|c|c|c|}
\hline & Glaber & number of cases \\
\hline 1. & $\mathrm{~N}+\mathrm{pp}$ & 78 \\
\hline 2. & $\mathrm{pp}+\mathrm{N}$ & 8 \\
\hline & & 86 \\
\hline
\end{tabular}

Table 2. Ordering in NPs of Glaber's edition of Wróbel's translation of the Gallicanum

Let me now comment on the data in more detail. The three instances where Wróbel's translation shows preposed possessive pronouns (Table 1 point 2 ) are all retained by Glaber, as illustrated in (1) below, which first presents the data

${ }^{12}$ Importantly, the instances where I compare the additions in the two Polish versions of the text are analysed within the confines of the text limited by the appearance of the first 100 Latin NPs, i.e. in the text of Ps. 1.1-8.4. Let me add at this point that the verse numbers are absent from both versions of the Żołtarz but I supply them here after the standard modern edition of the Gallicanum, i.e. the Stuttgart Bible, to facilitate reference and properly document the presented data.

${ }^{13}$ I do not pay particular attention to the lexical layer, though sometimes the differences are quite significant.

${ }^{14}$ The abbreviation stands for possessive pronouns. 
from the Gallicanum, followed with Wróbel's rendition and then with Glaber's text. The possessive pronouns are underlined throughout the paper for the convenience of the reader.

(1) a. 2.3 vincula eorum 'their fetters' $>$ gych przekowi $>\underline{\text { ich }}$ więzienie

b. 2.3 iugum ipsorum 'their-refl. yoke' $>$ gych yarzmo $>$ ich iarzmo

c. 2.7 filius meus 'my son' > moy myli shin 'my beloved son' >

It is now clear that the remaining five cases represent instances of the shift in the direction opposite to that reported by Migdał (1991) and Cybulski (1996). These cases are quoted below.

(2) a. 1.3 fructum suum 'their-refl. fruit' $>$ owocz swoy $>\underline{\text { swoy }}$ owoc

b. 2.13 ira eius 'his wrath' $>$ gnyew yego $>$ iego gniew

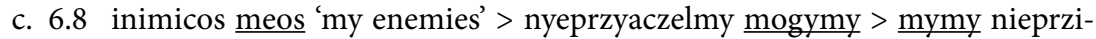
jacielmi

d. 7.17 verticem ipsius 'their-refl. crown-of-the-head' > shiyą yego $>$ iego szyię

e. 7.17 iniquitas eius 'his iniquity' > zloscz yego 'his anger' > iego złosć

The juxtaposition of the results of the above examination follows in Table 3 below.

\begin{tabular}{|c|c|c|c|}
\hline & Wróbel & Glaber & number of cases \\
\hline 1. & $\mathrm{~N}+\mathrm{pp}$ & $\mathrm{N}+\mathrm{pp}$ & 78 \\
\hline 2. & $\mathrm{~N}+\mathrm{pp}$ & $\mathrm{pp}+\mathrm{N}$ & 3 \\
\hline 3. & $\mathrm{pp}+\mathrm{N}$ & $\mathrm{pp}+\mathrm{N}$ & 0 \\
\hline 4. & $\mathrm{pp}+\mathrm{N}$ & $\mathrm{N}+\mathrm{pp}$ & 86 \\
\hline & TOTAL & & \\
\hline
\end{tabular}

Table 3. The classification of Glaber's corrections in Wróbel's translation of the Gallicanum

As clearly transpires from the data discussed above, the NPs analysed in my study do not show a single case of the shift reported by Migdał (1991) and Cybulski (1996). This by no means signifies the incorrectness of their observation as the eleven cases of pp+N (Wróbel) $>\mathrm{N}+\mathrm{pp}$ (Glaber) are attested in Psalm numbers higher than $8 .{ }^{15}$ The importance of my data does not lie in contradicting the views of previous researchers. On the contrary, Migdał's research, which focused on classifying Glaber's interventions, naturally put to the fore those instances of corrections which illustrated Glaber as an executor of Polish Biblical style in accordance with the profile of Migdał's study. Since the movement in the opposite direction cannot be motivated by the same incentive,

15 This is what I infer from the fact that the first of the two quoted examples appears in 9.15, i.e. 9.16 according to the Stuttgart Bible numbering. 
Migdał remains (almost) silent about such cases, allocating them together with other unspecified interventions. To be precise, Migdał (1991: 94) remarks that the corrections she discusses do not cover the whole range of Glaber's interventions and remarks that it is hard to interpret bidirectional rearrangements. So this is probably where the data from Table 3 above belong. Note, however, that even though my corpus covers only a fraction of the whole text of the Psalms, the five rearrangements in the direction opposite to that reported in the literature, with none at all of the type $\mathrm{pp}+\mathrm{N}>\mathrm{N}+\mathrm{pp}$, may suggest a higher number of rearrangements in the direction reported in my data, though the accumulation in Ps. 1.1-8.4 of examples of the type $\mathrm{N}+\mathrm{pp}>\mathrm{pp}+\mathrm{N}$ may of course be coincidental. Most importantly, however, these rearrangements are not explicitly reported by Migdał in contrast to the observation concerning the opposite tendency. In effect, one gets the mistaken impression of Glaber's contribution to Wróbel's text.

\subsection{Text which did not (directly) correspond to the Gallicanum}

Let me now move on to the remaining data from my corpus, to see how Glaber treated Wróbel's text which did not (directly) correspond to the Gallicanum, although it was presented as the text of the translation rather than the commentary. There are 30 contexts relevant here. This means that between 1.1 and 8.4, i.e. within the portion of the text which contains the first 100 Latin NPs of the specified type, there are as many as 30 contexts in which either one or both texts show an NP containing a possessive pronoun while there is no corresponding NP in the Latin source or nothing at all that corresponds to the content of the NP in the Polish text(s). In effect, the conclusions following from these data may show us whether the predominantly postpositive ordering of possessive pronouns in the data discussed so far is to be associated with the requirements of Polish Biblical style or represents a realisation of the medieval Biblical translation, which strove to render the source text as closely as possible, often at the expense of style and grammar. ${ }^{16}$ Observe that the data analysed so far could not be unambiguously interpreted in that respect.

${ }^{16}$ Naturally, the postpositive ordering came to be a characteristic of Polish Biblical style (cf. Kossowska 1962: 205; Rospond 1962: 164; and Koziara 1998: 64) precisely because this ordering resulted from the fidelity of the rendition. The same process is reported in Czech (Rospond 1962: 163). The fact that this ordering came to characterise Protestant renditions, not based on the Vulgate, confirms the evolution of the status of this ordering from a calque to a characteristic of style.

Interesting material in the context of the discussion of the relationship between fidelity and grammaticality is offered by Richard Rolle's translation of the Psalter. It is a $14^{\text {th }}$-century English rendition also intended for the benefit of a lady (an anchoress, to be precise) and executed in a very similar style. Rolle prioritises the fidelity of the rendition over grammaticality and produces clauses in strict imitation of the Latin syntax, contravening the rules of English grammar (cf. Charzyńska-Wójcik in press b). 
Representative data are quoted in (3)-(6) below, where the a. examples show the full verse from the Gallicanum, while Wróbel's and Glaber's texts are given in examples b. and c. respectively. The relevant NPs are italicised, with the possessive pronoun underlined, as has been done so far. The data in (3) and (4) instantiate added text, (5) and (6) show contexts in which the Polish texts depart structurally from the Latin original but (try to) stick to the content of the Gallicanum.

(3) 5.10

a. Quoniam non est in ore eorum veritas: cor eorum vanum est.

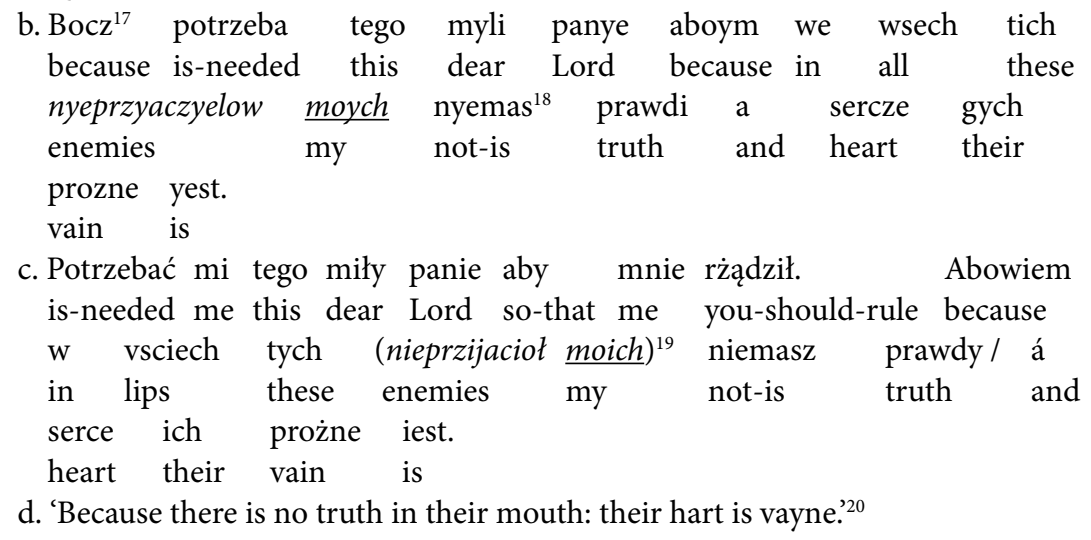

${ }^{17}$ For the sake of the clarity of the presentation, I gloss the Polish examples in a simplified way, i.e. without providing the information concerning some complex grammatical forms and choosing the simplest English equivalents of the Polish words. Where necessary, I relied on the dictionary of older Polish (Słownik staropolski), which is now available in scans at: https://pjs. ijp-pan.krakow.pl/sstp.html [20.06.2016].

${ }_{18}$ The manuscript divides the negative particle between two lines here, with nye left at the end of one line and mas placed at the beginning of the next line, without any mark indicating that the word is split. However, I decided on the joined-up spelling on the strength of the following facts:

(i) All other instances of the negative particle followed by the verb are spelt together. This, however, is not a sufficient reason as I intend to represent the text as it stands rather than to correct the scribe; yet in some cases (precisely like this one) the scribe needs to be interpreted, especially in view of what follows in (ii) and (iii) below.

(ii) Most words split between two lines are not accompanied by the mark indicating the split double hyphen with an oblique slant (cf. Houston 2013 for a hypothesised development of this symbol).

(iii) Sometimes the split mark is placed where the two items placed at the end of one line and at the beginning of the next one are clearly meant to be spelt separately: $k$ torzi=mnye (in 4.7).

${ }^{19}$ Glaber occasionally uses brackets to mark the text that is added to the Gallicanum.

${ }^{20}$ Throughout the paper, I resort to an early Modern English translation of the Gallicanum, i.e. the Douay-Rheims Bible, to provide English equivalents of the Latin verses where these are presented in full. The Douay-Rheims Bible Psalter was first printed in 1610 as the second volume of the Old Testament (cf. Charzyńska-Wójcik 2013: 90-93). I present an exact replica of the text, retaining all spelling intricacies of the original edition. 
(4) 3.4

a. Tu autem domine susceptor meus es et gloria mea, et exaltans caput meum.

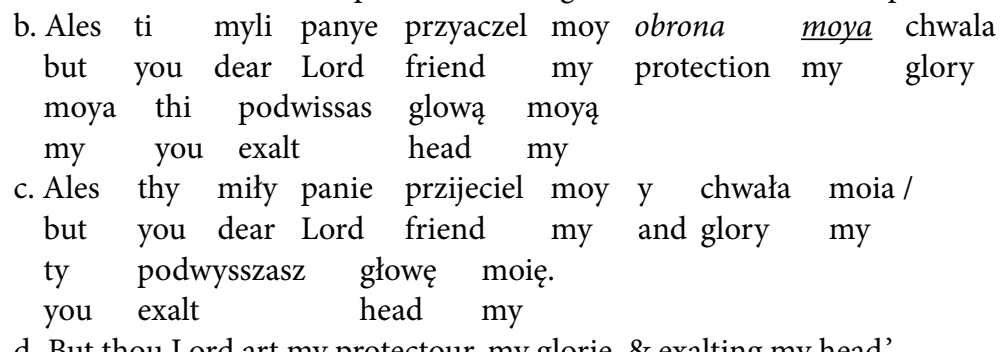

d. But thou Lord art my protectour, my glorie, \& exalting my head.'

(5) 3.8
a. dentes peccatorum 'teeth of the sinful'
b. zambi gych 'their teeth'
c. $\underline{\text { ich zęby }}$

(6) 2.13

a. Cum exarserit in breui ira eius, beati omnes qui confidunt in eo.
b. Kyedissyą gnyew yego rozpaly ywss wrichle: blogoslawyeny when+refl. wrath his burns soon blessed czy wsisczi ktorzi wnym duffanye swe pokladayą those all who in-him trust their-refl. place
c. Kiedy sie iego gniew rozpali á tho będzie w richle / when refl. his wrath burns and it shall-be soon bogoslawieni wszitci ktorzy wnim duphanie swe pokładaią. blessed all who in-Him trust their-refl. place
d. 'When his wrath shal burne in short time, blessed are al, that trust in him.'

As already noted, all the contexts discussed now appear within the translation rather than the commentary, i.e. in the text representing the Biblical genre. Regardless of whether they represent additions (i.e. text added for the sake of clarity) or restructuring of the source, these data analysed separately for each text can offer insight into Wróbel's and Glaber's approach to the syntax of the NP and can be individually compared to the two translators' (or the translator's and the editor's) approach to the syntax of NPs representing translations of the corresponding structures. Moreover, those contexts which share the relevant NPs can be analysed with respect to how Glaber treated these of Wróbel's NPs which do not structurally correspond to the Latin source.

Let me start with the data for Wróbel's text. Among the total of 30 contexts, Wróbel's text shows valid data in 28 instances, i.e. there are 28 contexts in his text which contain a head noun and a possessive pronoun (in two of the contexts the NPs of the relevant type are only exhibited by Glaber's text). 


\begin{tabular}{|c|c|c|}
\hline & Wróbel & number of cases \\
\hline 1. & $\mathrm{~N}+\mathrm{pp}$ & 20 \\
\hline 2. & $\mathrm{pp}+\mathrm{N}$ & 8 \\
\hline & TOTAL & 28 \\
\hline
\end{tabular}

Table 4. Wróbel's text

As transpires from the table above, Wróbel clearly favours the postnominal placement of possessive pronouns, but here his consistency is much lower than in the case of the data given in Table 1 above. This may suggest that the postnominal orders recorded in the text result from his adherence to the word order of the Latin source, which in turn can be taken to mean that he prioritised the fidelity of the rendition over the stylistic choices associated with the Biblical genre. This is a rather unexpected conclusion considering the amount of additions in his translation, but I will leave it at that for the time being.

When it comes to Glaber's text, only 17 out of the 30 contexts show the NPs consisting of a possessive pronoun and a head noun, with two of them being added with respect to Wróbel's text. This means that 15 of the contexts overlap, i.e. both Polish texts show NPs of the relevant type. The reduced number of contexts in Glaber's text with respect to Wróbel's is the joint effect of two phenomena. First of all, Glaber often (but not consistently) removes Wróbel's additions from the translation and places them in the sections with the commentary. Secondly, he occasionally changes Wróbel's text so that it adheres to the Latin source more closely, in effect not exhibiting NPs with possessive pronouns where Latin does not show them but having a clause or an unaccompanied noun, in agreement with the Latin source (cf. 7 and 8 below). The data for Glaber's text are presented in the table below.

\begin{tabular}{|c|c|c|}
\hline & Glaber & number of cases \\
\hline 1. & $\mathrm{~N}+\mathrm{pp}$ & 14 \\
\hline 2. & $\mathrm{pp}+\mathrm{N}$ & 3 \\
\hline & TOTAL & 17 \\
\hline
\end{tabular}

Table 5. Ordering in NPs of Wróbel's translation of the Gallicanum

(7) 4.4
a. cum clamauero when I-will-call
b. do nyego wolanye to him supplication
c. będę kniemu wolal
modlitwi moyey podnyossą
I-will to-Him call

$\begin{array}{lll}\text { moditwi } & \text { moyey } & \text { podnyossą } \\ \text { of-prayer } & \text { my } & \text { I-will-raise }\end{array}$


(8) 7.5
a. merito
due-reward
b. pozitkw
due-reward my
c. pożytku
due-reward

At first glance, the data presented in Tables 4 and 5 contain exactly the type of relocations reported by Migdał (1991) and Cybulski (1996), i.e. from Wróbel's $\mathrm{pp}+\mathrm{N}$ (8 instances) to $\mathrm{N}+\mathrm{pp}$ in Glaber's work, as the reduced number of the $\mathrm{pp}+\mathrm{N}$ contexts in Glaber's data ( 3 instances) seems to suggest. However, an examination of the examples does not confirm this impression: out of Wróbel's eight offensive NPs, i.e. of the $\mathrm{pp}+\mathrm{N}$ structure, as many as five do not have structurally corresponding contexts in Glaber. They are quoted below.

(9) 2.1

a. Qvare fremuerunt gentes, et populi meditati ${ }^{21}$ sunt inania.

$\begin{array}{llllll}\text { b. K czemv y } \mathrm{kw} \text { ktoremv } & \text { swemv } & \text { pozitkw } & \text { tak } \\ \text { to what and to which } & \text { their-refl. due-reward } & \text { so } \\ \text { prikrossyą pogany rosgnyewaly } & \text { a lud } & \text { zidowsky } & \text { przecz } \\ \text { severely+refl. pagans } & \text { raged } & \text { and people } & \text { Jewish } & \text { why } \\ \text { prozne missly } & \text { zaczinal } & & & & \\ \text { vain thoughts } & \text { started } & & & & \end{array}$

${ }^{21}$ As a matter of fact, in the printed Żołtarz from 1539 available at: http://www.dbc.wroc.pl/ dlibra/doccontent $\mathrm{id}=7028 \&$ from $=\mathrm{FBC}[20.06 .2016]$ this page is missing and has been supplied in the handwritten form (imitating the font types used throughout the book). The word is written there as medicati instead of meditati. (In the original printed version the word was spelt as meditati, as evidenced by a copy where the page has been preserved, cf. for example: http://www. dbc.wroc.pl/dlibra/docmetadata?id=2774\&from=publication [20.06.2016].) It is most probably due to the fact that the letters $\langle\mathrm{c}\rangle$ and $\langle\mathrm{t}\rangle$ are indistinguishable in many script types, giving rise to interpretational indeterminacy. This naturally does not constitute a problem in contexts where the quality of $<\mathrm{c}>$ is that of [k], while $<\mathrm{t}>$ corresponds to [t]. Confusion is likely in the contexts where $\langle\mathrm{t}\rangle$ is pronounced as [ts] - a change attested in post-Classical Latin almost universally across Europe (Rigg 1999: 79). The change was reflected in the spelling - such contexts started to be spelt with $<\mathrm{c}>$ because they coincided phonetically with the results of an earlier phonological change, which took place already in Late Antiquity, when the originally bidirectional one-to-one relationship (typical of the pronunciation of Latin) between $[\mathrm{k}]$ and $\langle\mathrm{c}\rangle$ changed. In particular, $[\mathrm{k}]$ when followed by a front vowel, i.e. [i] or [e], was palatalised but the change was not accompanied by a respelling. As a result of this change, $<\mathrm{c}>$ started to denote both $[\mathrm{k}]$ and its palatalised version (pronounced slightly differently in different areas: "the resulting sound was varied from region to region;" Janson 2002/2004: 108). In effect, [ts] spelt with $<\mathrm{c}>$ reflects both the original $[\mathrm{k}]$, in line with the long tradition, and the original $[\mathrm{t}]$, in accordance with the new rule. Yet there were plenty of manuscripts in which the older $<\mathrm{t}>$-spelling was preserved. In effect, [ts] $<$ [t] tended to be spelt either with $\langle\mathrm{t}\rangle$ or with $\langle\mathrm{c}\rangle$, as in sapientia vs. sapiencia. The confusion is, therefore, purely graphic in most cases. Because in contexts where $<t>$ was pronounced as $[t]$, it was never spelt as $\langle\mathrm{c}\rangle$, the spelling meditati is clearly as a mistake. 
c. $\mathrm{K}$ czemu sie tak przykro rozgniewali pogani/ A lud to what refl. so severely raged pagans and people zydowski prozne rzeczy poczynal. Jewish vain things started

d. 'VVhy did the Gentiles rage, and peoples meditate vaine things?'

(10) 2.3

a. Dirumpamus vincula eorum, et proijciamus a nobis iugum ipsorum.

b. I mowyly rozerwyemi gych przekowi y gych wazli / and they-said we-will-break their fetters and their bonds a zrzuczmi ssyebye gych yarzmo

and let-us-cast-away from+us-refl. their yoke

c. Rozerwimy to ich więzienie / á zrzućmyy

we-will-break that their bond and let-us-cast-away z siebie ich iarzmo.

from us-refl. their yoke

d. 'Let vs breake their bondes a sunder: and let vs cast away their yoke from vs.'

(11) 4.7

a. nos

us-ACC

b. $\underline{\text { nasze }}$ dusze

our souls

c. nas

us-ACC

(12) 5.13

a. ... Domine vt scuto bonę voluntatis tuę: coronasti nos.

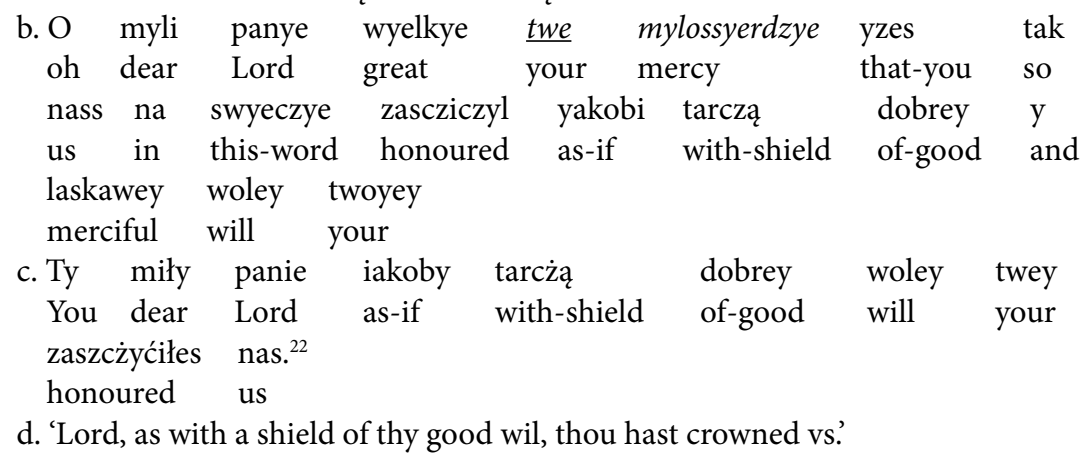

${ }^{22}$ Since twe mylossyerdzye 'your mercy' does not represent translation proper (as can be seen in $12 \mathrm{a}$, there is nothing in the source text that corresponds to it), Glaber relocated the phrase to the commentary. It ought to be noted that he did reverse the order within the PN to $\mathrm{N}+$ pp: mitosierdzie twoie, but in this paper I am not concerned with word order in the comments as they represent a different textual genre. 
(13) 7.10

a. Consumetur nequitia peccatorum, et diriges iustum: scrutans corda et renes deus.

b. Uczin to myli panye abi gych zloscz bila dokonana do this dear Lord so-that their anger should-be done a ti myli panye powissyss sprawyedlywego

and You dear Lord will-exalt the-just-one

ti ktori znas sercza y missly lvczkye

You who know hearts and thoughts human

c. Niechay będzie dokonana żłosć grzesznikow/

let be done anger of-the-impious

á (ty panie) boże ktory znasz sercza y mysli ludskie and You Lord God who know hearts and thoughts human powysszysz sprawiedliwego. will-exalt the-just-one

d. 'The wickednesse of sinners shal be consumed, and thou shalt direct the iust, which searchest the hart and raynes ô God.'

As is clear, the absence of $\mathrm{pp}+\mathrm{N}$ orders in examples c. above does not follow from Glaber's relocating the $\mathrm{pp}$ to the postnominal position in any given case. But his data do show a lower number of $\mathrm{pp}+\mathrm{N}$ contexts. This, however, is a side effect of a different tendency that seems to be at work here: rather than crediting Glaber with implementing Polish Biblical style, he can be shown to discipline the Polish text to the Latin source, i.e. he reshapes Wróbel's text to syntactically converge with the Gallicanum.

The three of Glaber's NPs with the prepositional ordering represent retentions of Wróbel's wording (cf. 14 and 15 below) and a relocation of the postpositional order to the prepositional one (cf. 16), echoing the tendency we observed with respect to the data which corresponds to the Latin $\mathrm{N}+\mathrm{pp}$ contexts (cf. Table 3 ).

(14) 3.7

$\begin{array}{lllllll}\text { moy } & \text { myli } & \text { panye } & \text { boze } & >\text { moy } & \text { mily } & \text { panie } \\ \text { my } & \text { dear } & \text { Lord } & \text { God } & >\text { my } & \text { dear } & \text { Lord }\end{array}$

(15) 7.3

$\begin{array}{llll}\text { moy } & \text { przesladowcza } & >\text { moy } & \text { przesladowcża } \\ \text { my } & \text { persecutor } & >\text { my } & \text { persecutor }\end{array}$

(16) 3.8

dentes peccatorum > zambi gych > ich zęby teeth of-the-sinful $>$ teeth their $>$ their teeth

In sum, the predominant order of these data is postpositive in both texts and it is clear that the ordering cannot be seen as an attempt to produce a maximally close rendition on Wróbel's part as most of these examples do not represent translations and those that come close to being ones (such as 16 above) show structural departures from the source on a more profound level, and as 
such they cannot be seen as an implementation of a close rendition. Observe that Wróbel's and Glaber's texts and their relationship to the source and to each other constitute perfect data for that kind of analysis since the issue would be impossible to resolve when analysing Biblical translations per se. How these orders are to be interpreted is not entirely clear but since they represent the Biblical text (despite not always being translations) the ordering must be seen as produced by Wróbel for its own sake. It could thus be said, albeit very cautiously, that these orders represent what Wróbel saw fit for this type of text, i.e. the postpositive ordering in these instances can be interpreted as the emerging property of Polish Biblical style, with all reservations due here (cf. also fn. 17). In contrast, the corresponding data found in Glaber's text seem to suggest that he focused on the fidelity of the translation, hence so many instances of reversion to the source, either realised as the relocation of added matter to the commentary or restructuring the text to match the source more closely.

\subsection{Latin $\mathrm{N}+$ pps without a structurally parallel Polish rendition}

Let me finally comment upon the cases excluded from the initial 100 sets of Latin - Wróbel - Glaber cases, i.e. instances where the Latin N+pp does not receive a structurally parallel Polish rendition. These 14 contexts fall into several types, which, however, cannot be said to represent a tendency, since for a pattern of one type, there is a reverse pattern represented as well. Besides, the small number of examples does not allow for valid generalisations. Let me only remark that among these data there are five instances where Glaber's corrections show the same tendency as in the data just analysed, i.e. towards adherence to the Latin original (cf. 17 below), five cases where one or both texts lack the pronoun (cf. 18), and 2 instances where the possessive is replaced with the demonstrative (cf. 19). Finally, there are two examples, each representing a type of their own (cf. 20).

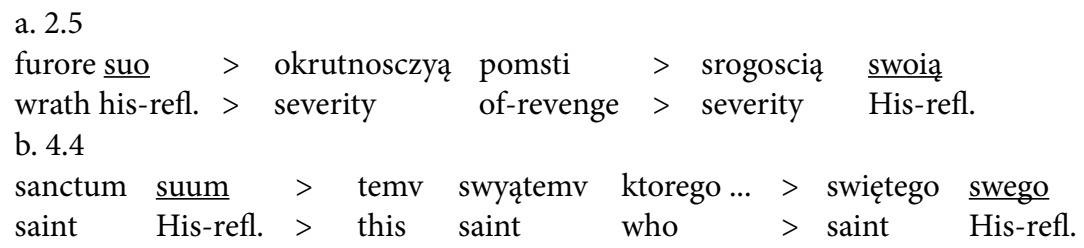

(18)

a. 6.7
lachrimis $\underline{\text { meis }}>$ lzamy $>$ tzami
tears $\mathrm{my}>$ tears $>$ tears

b. 2.8

hęreditatem tuam $>$ dzedzitwo twoye $>$ dziedzicztwo heritage your $>$ heredity your $>$ heredity 
(19)

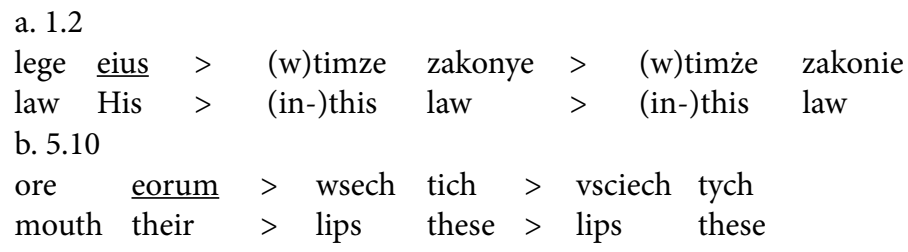

(20)

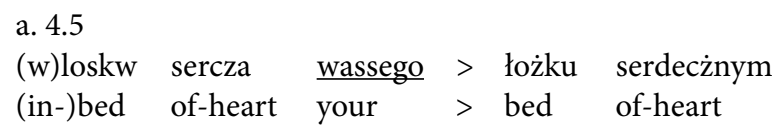

b. 4.2

iusticię meę > myą vsprawyedlywya $>$ mnie vsprawiedliwia justice my $>$ me justifies $>$ me justifies

\section{Conclusion}

In sum, the data presented above allow us to draw the following generalisations: the 86 classifiable three-part sets, i.e. renditions of Latin NPs of the $\mathrm{N}+\mathrm{pp}$ type into structures with the same constituents (Section 3.1) show Wróbel as a translator striving to achieve maximum fidelity in accordance with Jeromian's approach to scriptural translation. In the analysed sample of Wróbel's text there are as many as 83 exact replicas of the Latin structure, i.e. $\mathrm{N}+\mathrm{pp}$ contexts and only 3 instances of the prenominal placement of possessive pronouns. In contrast, Glaber does not appear as consistent, with none of Wróbel's three prenominal orders reverted to match the requirements of style, a tendency he is credited with by Migdał (1991). On the contrary, Glaber retains all Wróbel's cases of $\mathrm{pp}+\mathrm{N}$ and an additional five of Wróbel's $\mathrm{N}+\mathrm{pp}$ orders are reversed by Glaber to the $\mathrm{pp}+\mathrm{N}$ order - a substantial amount of relocations in a small sample of data, considering the total of eleven rearrangements in the opposite direction he is credited with. ${ }^{23}$

Further data analysed in the paper (Section 3.2), however, do not support the above generalisation concerning Wróbel, as here we focus on his additions to the text and his departures from the structure of the Gallicanum. All noun phrases containing personal pronouns ( 28 in total in this data set) are ordered according to Wróbel's own stylistic preferences, with 20 postpositive and 8 propositional phrases. Glaber's interventions here fall into two types both

${ }^{23}$ This does not indicate that I question the existence of the reported examples, on the contrary: I am aware of at least two relocations of this type in later parts of the Psalter. What I want to emphasise is the relatively high number of instances of the opposite tendency observed in a small corpus. As already noted, a detailed analysis of Migdał's examples is presented in Charzyńska-Wójcik (in prep.). 
representing the same tendency: relocations of added matter into the section devoted to the commentary and instances of disciplining Wróbel's text to match the source more clearly on the structural level. In effect, Glaber's text has only $17 \mathrm{NPs}$ of the relevant type (14 postpositive vs. 3 prepositional ones). Importantly, in parallel to Section 3.1, the analysis of the data does not support the view of Glaber as the executor of Polish Biblical style either. The last set of data (Section 3.3) on its own does not allow for valid conclusions but analysed together with the data presented in Sections 3.1 and 3.2 strengthens the former conclusion concerning Glaber: there does not seem to be any conscious language programme behind Glaber's syntactic rearrangements analysed here. The predominant direction of his syntactic interventions, however, confirms his involvement in aligning the Polish text to the Latin source.

It could of course be objected that the above conclusions are drawn from limited data and are therefore not valid. While the objection is undeniably true and any inferences made with reference to either Wróbel's or Glaber's translation priorities certainly require further studies based on a much more extensive corpus, it is precisely the limited character of my data that supports the working hypothesis of this paper. In particular, that the two versions of the text are not sufficiently researched. The precious little that we seem to know about Glaber's syntactic corrections is not supported even by the analysis executed on a small corpus. In effect, the degree of Glaber's intervention into Wróbel's text is underappreciated and the translation shown in the manuscript and in the printed version is conceived of as the same text, only tuned up by Glaber's standardising tendencies and his minor stylistic and syntactic interventions. The fact that a corpus of such a small size could illustrate all these issues so vividly indicates that the extent of Glaber's interventions merits him the authorship of the printed work.

\section{Post scriptum}

The joint denotation 'Wróbel's Żołarz' used in the literature to refer either to the original work by Wróbel or to its substantial reworking produced by Glaber is erroneous. The extant manuscript, which we take after Brückner (1902) to accurately represent Wróbel's work (as far as possible) and the printed edition prepared by Glaber should in fact be treated as two different texts. The former should be called Wróbel's Żołtarz and the latter should be referred to either as Glaber's Żottarz, the Wróbel-Glaber Żottarz or, as suggested by Cybulski (2008), the Glaber-Wróbel Żołtarz. To be precise, Cybulski (2008) contains two references of this type, and he makes them without arguing the point I am making in this paper but I consider Cybulski's choice of the attribution an important step in the discussion, even if it was not meant as such by the 
author. The same comment is due with respect to Cybulski's predecessor in this respect, namely Łoś (1915), who calls the printed work "przeróbka Glabera" (Glaber's reworking). Whether he means that Wróbel's and Glaber's productions should be viewed as different texts I doubt in view of the contents of his remaining discussion but, I see this as the seed of my line of argument.

I hope to have signalled in the course of the paper that Glaber's contribution to Wróbel's work far exceeds what we understand as editorial intervention. The impressively detailed study of Migdał devoted to comparing the two versions of the Żottarz shows Glaber as an important and very conscious participant in the process of standardisation of the Polish language. This is undeniably true, but it shows Glaber's interventions from the perspective of a (more or less) systematic language programme. In effect, the extent of Glaber's intervention into Wróbel's work is still underestimated in the literature and the received view does not do justice to Glaber's genuine involvement in the creation of the printed Żottarz. The far-reaching changes he introduced into the final product would not be allowed under the modern understanding of the notions of the author and editor, which is probably what thwarts our understanding of the relationship between the two versions of the Żoltarz. The roles of the author and of the editor were still conceived of very differently in the Middle Ages and the early Renaissance (cf. Charzyńska-Wójcik 2016b), to the extent that there was a creative continuum, which encompassed the author, compiler, translator, and even the scribe, i.e. an equivalent of a later editor (cf. Taylor 2015: 199, 210). All participants contributed in various degrees to the final product, and their responsibilities were not clearly delineated: they mellowed on the (printed or hand-written) page. This is what legitimised Glaber's interventions. However, the ensuing evolution of the notion of the author and editor has prevented us from understanding the true nature of Glaber's participation in preparing the printed version of the Żottarz.

\section{References}

BADowska Małgorzata (2011). Zagadka tożsamości szesnastowiecznego kopisty, czyli o Hieronimie, kapłanie z Poznania, słów kilka. Kwartalnik Językoznawczy 3, 97-105. BRÜCKNer Aleksander (1902). Psałterze polskie do połowy XVI w. Kraków: Akademia Umiejętności.

Charzyńska-Wójcik Magdalena (2013). Text and Context in Jerome’s Psalters: Prose Translations into Old, Middle and Early Modern English. Lublin: Wydawnictwo KUL.

Charzyńska-Wójcik Magdalena (2015). The Anatomy of Two Medieval Texts: False Facts and Factual Frauds. Lecture delivered on 10.12.2015 in the Institute of English of the University of Warsaw. 
Charzyńska-Wójcik Magdalena (2016a). The anatomy of two medieval translations of the Psalter. In Translation and Meaning, Łukasz Bogucki, Barbara LewaNDowska-Tomaszczyk and Marcel Thelen (eds.), 189-208. Frankfurt a. Main: Peter Lang.

Charzyńska-Wójcik Magdalena (2016b). Parallax: looking at the medieval through the modern lens. Roczniki Humanistyczne 64, 49-63.

CharzyńsKa-WójCik Magdalena (2016c). The Dactyloscopy of Medieval Translations. Lecture delivered on 11.04.2016 in the Faculty of English of Adam Mickiewicz University in Poznań.

CharzyŃska-Wójcik Magdalena (in press a). Między przekładem wiernym a parafrazą: wpływ czynników socjolingwistycznych na wybór techniki tłumacza. To appear in Między tekstem a Kulturą, Aleksandra R. KNAPIK, Piotr P. CHruszCZEWSKI (eds.).

Charzyńska-Wójcik Magdalena (in press b). Translations or Transgressions? Syntactic Convergence with the Source in Two Medieval Vernacular Psalters. To appear in Constraints on Structure and Derivation in Syntax, Phonology and Morphology. Anna Bloch-Rozmej, Anna Bondaruk (eds.). Frankfurt a. Main: Peter Lang.

ChARZyŃska-Wójcik Magdalena (in prep.). Women as Muses of Psalter Translators.

CyвULsKi Marek (1996). Staropolskie przekłady Psałterza. Łódź: Łódzkie Towarzystwo Naukowe.

Cyвulski Marek (2008). O języku najstarszych psałterzy polskich. Poradnik językowy $10,23-40$.

Douay-Rheims Bible $=(1609-10)$. The Holie Bible Faithfvlly Translated into English, ovt of the Avthentical Latin Diligently Conferred with the Hebrew, Greeke, and Other Editions in Diuers Languages: with Argvments of the Bookes, and Chapters: Annotations: Tables: and Other Helpes, for Better Vnderstanding of the Text: for Discouerie of Corrvptions in Some Late Translations and for Clearing Controversies in Religion. Volume II. Doway: Lavrence Kellam, http://archive.org/details/holiebiblefaithf02engl [20.06.2016].

Houston Keith (2013). Shady Characters: The Secret Life of Punctuation, Symbols and other Typographical Marks. New York and London: W. W. Norton \& Company.

Janson Tore (2002/2004). A Natural History of Latin. Translated and adapted into English by Merethe Damsgård Sørensen and Nigel Vincent. Oxford: Oxford University Press.

KAMIENiECKi Jan (2008). Osobliwości leksykalne “Żołtarza” Walentego Wróbla. In Wyraz i zdanie w językach słowiańskich: opis, konfrontacja, przekład. 6, Slavica Vratislaviensia 147, Michał SARnowski, Włodzimierz Wysoczański (eds.), 147-151. Wrocław: Wydawnictwo Uniwersytetu Wrocławskiego.

KAmieniecki Jan (2009). “Żołtarz Dawidów” Walentego Wróbla - filologiczne i teologiczne osobliwości. In Język religijny dawniej i dziś (w kontekście teologicznym i kulturowym): materiały z konferencji, Gniezno, 22-24 września 2008. 4. Biblioteczka Poznańskich Studiów Polonistycznych Serii Językoznawczej 38, Paweł BorTkiewicz, Stanisław MikoŁajczak, Małgorzata Rybka (eds.), 209-218. Poznań: Wydawnictwo "Poznańskie Studia Polonistyczne".

KAMIEnieCKi Jan (2010). Nazwy miejscowe i osobowe w “Żołtarzu” Walentego Wróbla. Rozprawy Komisji Językowej Wrocławskiego Towarzystwa Naukowego 37, 59-64. 
KossowsKa Maria (1962). Z dziejów polskiego stylu psałterzowego. Język polski 42, 2-3, 135-148, 194-212.

Kossowska Maria (1968). Biblia w języku polskim. Poznań: Księgarnia Świętego Wojciecha.

KoziARa Stanisław (1998). O szyku zaimkowej przydawki dzierżawczej w polskich przekładach Psałterza (na przykładzie psalmu Miserere). Język polski 78, 1-2, $62-69$.

KwILECKA Irena (1978). O swobodnych średniowiecznych przekładach biblijnych (na przykładzie tłumaczeń francuskich, czeskich i polskich). Język polski 58, 87-98.

LELEWEL Joachim (1823). Bibljograficznych ksiąg dwoje, w których rozebrane i pomnożone zostaly dwa dzieła Jerzego Samuela Bandtke. Historja drukarń krakowskich - tudzież historja biblioteki Uniw. Jagiell. $w$ Krakowie a przydany katalog inkunabulow polskich. Volume I. Wilno: Nakładem i drukiem Józefa Zawadzkiego typografa imperatorskiego uniwersytetu.

Łoś Jan (1915). Przegląd językowych zabytków staropolskich do r. 1543. Kraków: Akademia Umiejętności.

Micha£owska Teresa (1995/2002). Średniowiecze. Warszawa: Wydawnictwo Naukowe PWN.

Migda£ Jolanta (1991). Glaberowskie korektywy gramatyczne w "Żołtarzu” Walentego Wróbla. Studia polonistyczne 16/17, 71-91.

Migda£ Jolanta (1999). O jezzku Andrzeja Glabera $z$ Kobylina. Studium normalizacji polszczyzny wczesnorenesansowej. Poznań: Wydawnictwo WiS.

PietKiewicz Ryszard (2002). Pismo Święte w języku polskim w latach 1518-1638. Sytuacja wyznaniowa $w$ Polsce a rozwój edytorstwa biblijnego. University of Wrocław, $\mathrm{PhD}$ dissertation.

PietKiewicz Ryszard (2010). Żołtarz proroka Dawida w przekładzie Walentego Wróbla. Studium bibliograficzno-bibliologiczne. In Ex Oriente Lux. Ksiegga Pamiatkowa dla Księdza Profesora Antoniego Troniny w 65. rocznice urodzin, Waldemar ChrosTOWSKI (ed.), 378-398. Warszawa: Stowarzyszenie Biblistów Polskich.

PietKiewicz Rajmund (2013). Tradycja rękopiśmienna polskich przekładów biblijnych od XIII do XVI wieku. Wroctawski przeglad teologiczny 21, 29-50.

Rigg A.G. (1999). Orthography and Pronunciation. In Medieval Latin: An Introduction and Bibliographical Guide, Frank Anthony Carl Mantello, A.G. Rigg (eds.), 79-82. Washington, D.C.: The Catholic University of America Press.

Rospond Stanisław (1962). Język renesansu a średniowiecza na podstawie literatury psałterzowo-biblijnej. In Odrodzenie w Polsce. Historia jezzka. Part 2, Maria Renata Mayenowa, Zenon Klemensiewicz (eds.), 61-181. Warszawa: Państwowy Instytut Wydawniczy.

UrbaŃCZyk Stanisław (ed.) (1953-2002). Słownik staropolski Vol. 1-11. Kraków: Instytut Języka Polskiego PAN. Available at: https://pjs.ijp-pan.krakow.pl/sstp.html [20.06.2016].

Stuttgart Bible $=$ Robert Weber (ed.) (1969). Biblia Sacta Iusta Vulgatam Versionem. Stuttgatt: Württembergische Biblenstalt.

TAYLOR Andrew (2015). Vernacular authorship and the control of manuscript production. In The Medieval Manuscript Book Cultural Approaches, Michael JoHnston, Michael Van Deussen (eds.), 199-214. Cambridge: Cambridge University Press. 
Wodecki Bernard (1998). Polish translations of the Bible. In The Interpretation of the Bible: The International Symposium in Slovenia, Jože Krasovec (ed.), 1201-1233. Sheffield: Sheffield Academic Press.

WRóBel Walenty (1528). Żołtarz Dawida Proroka i kroniczka rodzinna Jana Wyleżynskiego. The Kórnik Library of the Polish Academy of Sciences, BK Ms 7.

WróBel Walenty (1539). Psalterium Davidis, Żottarz Dawidów przez Mistrza Walantego Wrobla $z$ Poznania na rzecz polska wyłożony. http://www.dbc.wroc.pl/dlibra/ doccontent?id=7028\&from=FBC or http://www.dbc.wroc.pl/dlibra/docmetadata? id $=2774 \&$ from=publication [20.06.2016].

Instytut Filologii Angielskiej

Katedra Historii Języka Angielskiego i Translatoryki

Katolicki Uniwersytet Lubelski Jana Pawła II

al. Racławickie 14

20-950 Lublin

[mcwojcik(at)kul.pl] 